\title{
FUEL CELLS BASED ON SOME PROTON DYNAMICS PROPERTIES OF $\mathrm{H}_{2} \mathrm{O}_{2}$ COMPOUND
}

\author{
M. Davidović, ${ }^{1,}$, S. Linić ${ }^{1}$, A. Janićijević ${ }^{2}$, Z. Nedić ${ }^{3}$ and U. Mioc ${ }^{3}$ \\ 1,* Institute „Gosa“" Belgrade, Milana Rakića 35, Serbia \\ ${ }^{2}$ University of Belgrade, Faculty of Technology and Metallurgy, Belgrade, \\ Karnegijeva 4, Serbia \\ ${ }^{3}$ University of Belgrade, Faculty of Physical Chemistry, Belgrade, \\ Studentski trg 12-16, Serbia
}

\begin{abstract}
Electrochemical and conductive performances of the $\mathrm{H}_{2} \mathrm{O}_{2}$ compound in function of ambient conditions have been studied. A number of experimental techniques and theoretical calculations have been applied also to this problem. Namely, hydrogen peroxide with molecular formula $\left(\mathrm{H}_{2} \mathrm{O}_{2}\right)$ compound obtained from polyoxometalates acids which have small specific surface $\left(5 \mathrm{~m}^{2} / \mathrm{g}\right)$, will be the main subject of this study. The mentioned characteristics can be improved by plating particular conductors on transparent substrate in order to improve their properties.
\end{abstract}

Keywords: fuel cell, hydrogen peroxide, space charge region.

\section{INTRODUCTION}

Hydrogen peroxide is a very blue liquid, slightly more viscous than water, that appears colorless in dilute solution. It has strong oxidizing properties.

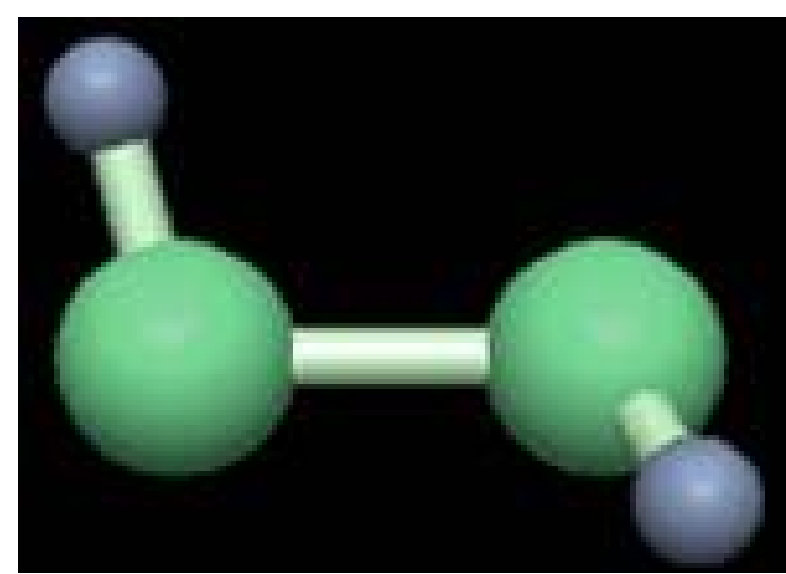

Figure 1.

By using proper electrocatalysts, $\mathrm{H}_{2} \mathrm{O}_{2}$ can be converted into hydroxyl radicals $\mathrm{OH}$, as shown in Fig. 1. Also hydrogen peroxide adopts a nonplanar structure of $\mathrm{C}_{2}$ symmetry. The properties of aqueous solutions of hydrogen differ from those of the neat material, reflecting the effects of hydrogen bonding between water and hydrogen peroxide molecules. Hydrogen peroxide and water form a eutectic mixture, exhibiting freezing-point depression (Fig.2).

*Corresponding author: milorad.davidovic@gmail.com

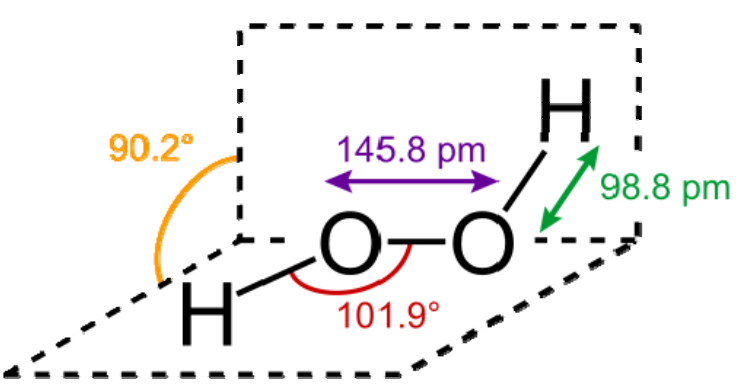

Figure 2.

The properties of hydrogen peroxide differ from those of neat material, reflecting the effects of hydrogen bonding between water and hydrogen peroxide molecules. Hydrogen peroxide decomposes exothermically into water and oxygen gas spontaneously, shown in Fig.3. and expressed by $(1)[1,2]$.

$2 \mathrm{H}_{2} \mathrm{O}_{2} \rightarrow 2 \mathrm{H}_{2} \mathrm{O}+\mathrm{O}_{2}$

This process is thermodynamically favorable. The rate of decomposition is dependent on the temperature and concentration of the peroxide as well as the $\mathrm{pH}$.

This mechanism can be employed as a means of producing humidified oxygen gas at high temperatures, as required sometimes to achieve reasonable kinetics. The resulting system is limited in energy density due to lost heat, but advances in catalysis are lowering the necessary activation energy of both oxygen and hydrogen peroxide reduction to the point where ambient systems may soon operate at compa- 
rable power densities. The electrochemical decomposition [3] analoguous with a theoretical half-cell voltage of $0,87 \mathrm{~V} / \mathrm{SHE}$ can be thought of as expressed in (2)

$\mathrm{HO}_{2}^{-}+\mathrm{H}_{2} \mathrm{O}+2 \mathrm{e}^{-} \rightarrow 3 \mathrm{OH}^{-}$

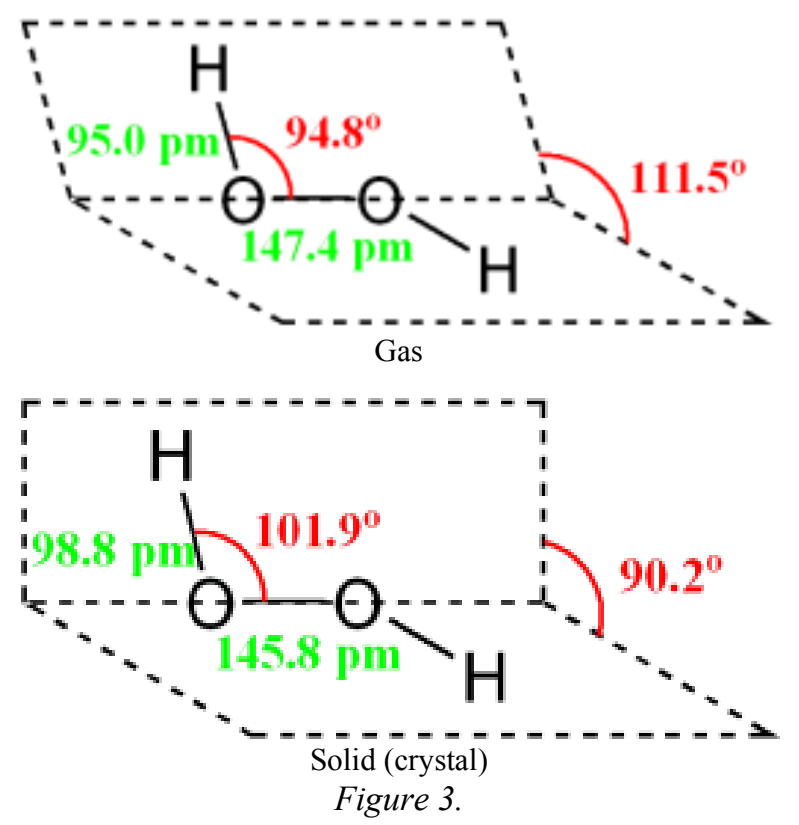

All potentials will be reported versus the standard hydrogen electrode (SHE). A second mechanism is the full reduction of the species to water, occurring at a theoretical half-cell potential of $1,87 \mathrm{~V}$, as shown by expression (3).

$\mathrm{H}_{2} \mathrm{O}_{2}+2 \mathrm{H}^{+}+2 \mathrm{e}^{-} \rightarrow 2 \mathrm{H}_{2} \mathrm{O}$

Reduction of $100 \%$ hydrogen peroxide in a fuel cell utilizing (3), would give a volumetric energy density of $8,0 \mathrm{kWh} / 1$.

As we know from previous study of different protonic species $\mathrm{H}^{+}, \mathrm{H}_{2} \mathrm{O}, \mathrm{H}_{3} \mathrm{O}^{+}, \mathrm{H}_{5} \mathrm{O}_{2}^{+}$similar dielectric behavior can be expected in this compound.

\section{USE OF $\mathrm{H}_{2} \mathrm{O}_{2}$ AS A FUEL-ROCKET PROPELLENT}

In this case, the $\mathrm{H}_{2} \mathrm{O}_{2}$ is typically passed over a catalyst, usually a silver mesh. The catalyst causes the oxygen and hydrogen in $\mathrm{H}_{2} \mathrm{O}_{2}$ to separate into $\mathrm{O}_{2}$ and $\mathrm{H}_{2}$ which then recombine explosively to form $\mathrm{H}_{2} \mathrm{O}$ (water).

\section{3. $\mathrm{NaBH}_{4}$ AS A FUEL FOR THE FUEL CELL}

The use of aqueous solution of $\mathrm{NaBH}_{4}$ as a hydrogen carrying medium is relatively a new deve- lopment. Combined with liquid hydrogen peroxide in a fuel cell (FC), shown by Fig. 4. and Fig.5, it brings some new advantages merits including [4], [5]:

- Compact and convenient all-liquid operation;

- Built-in supercapacitor effect as the carbon particles of the electrode and the all liquid anolyte/ catholyte form a solid-liquid double layer giving excellent short-time overload capability;

- Unitized regeneration is enabled since the catalytic electrodes and the membrane electrolyte only need to be hydrophilic, unlike ordinary $\mathrm{H}_{2} \mathrm{O}_{2}$ FC where both hydrophilic and hydrophobic phases are required to maintain a fragile three phase (gas-liquid solid) interface;

- Storage of the regenerated reactants in the $\mathrm{NaBH}_{4} / \mathrm{H}_{2} \mathrm{O}_{2} \mathrm{FC}$ is straight-forward

- Fast discharge/recharge is obtained through the fast dynamics of $\mathrm{H}^{+}$and $\mathrm{OH}^{-}$ions in a water-based solution

- Fast/deep charge/discharge is of paramount importance for Low Earth Orbit (LEO) applications, effectively translated into a high LEO cycle energy density.

Tuning of the restarted GMRES method, which then typically converges after 20 to 25 iterations.

The half-cell reaction scheme for a cathode based on hydrogen peroxide in acidic media includes a combination of direct hydrogen peroxide reduction and indirect oxygen reduction following decomposition. The reactions and associated standard [6] potentials at $298 \mathrm{~K}$ are as shown in expressions (4), (5) and (6).

$$
\begin{aligned}
& \mathrm{H}_{2} \mathrm{O}_{2}+2 \mathrm{H}^{+}+2 \mathrm{e}^{-} \leftrightarrows 2 \mathrm{H}_{2} \mathrm{O} \\
& \mathrm{E}^{\circ}=1.776 \mathrm{~V} \text { vs SHE } \\
& \mathrm{H}_{2} \mathrm{O}_{2} \leftrightarrows \mathrm{O}_{2}+2 \mathrm{H}^{+}+2 \mathrm{e}^{-} \\
& \mathrm{E}^{\circ}=0.682 \mathrm{~V} \text { vs SHE } \\
& \mathrm{O}_{2}+4 \mathrm{H}^{+}+4 \mathrm{e}^{-} \leftrightarrows 2 \mathrm{H}_{2} \mathrm{O} \\
& \mathrm{E}^{\circ}=1.229 \mathrm{Vvs} \mathrm{SHE}
\end{aligned}
$$

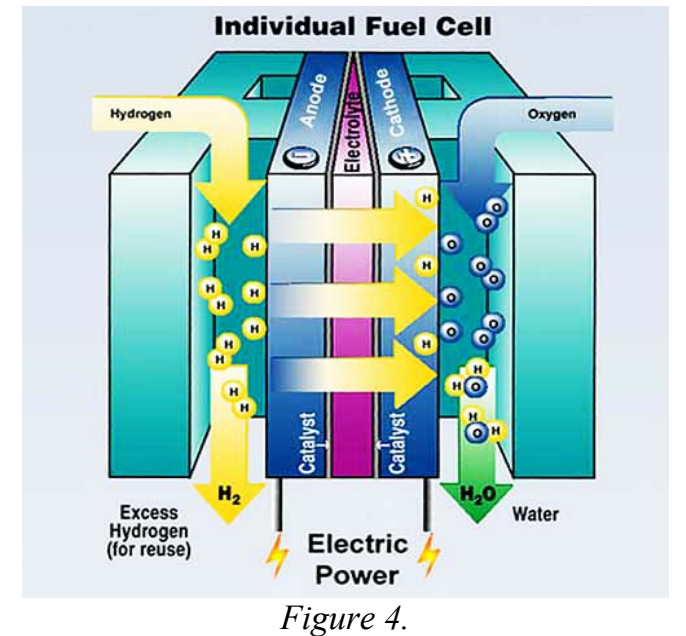




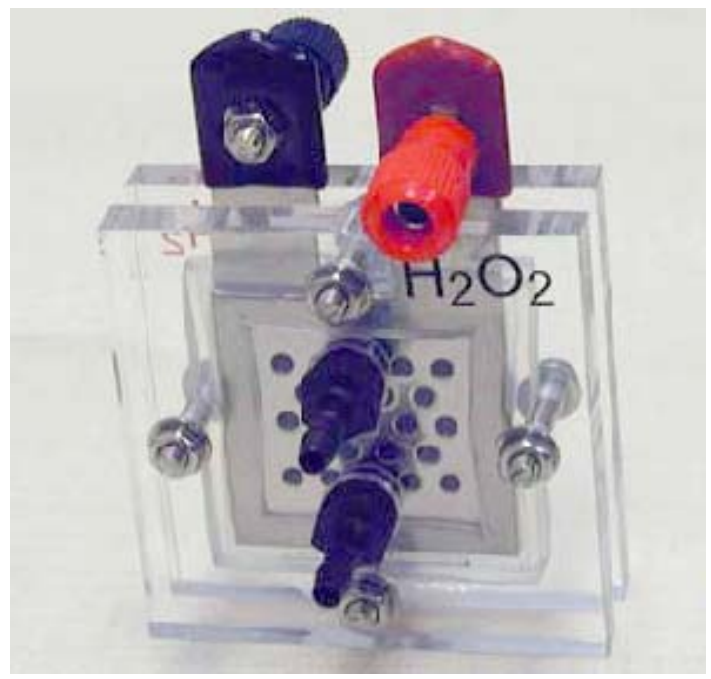

Figure 5.

The standard potential for direct hydrogen peroxide reduction, reaction 1 expressed as in (4), is more positive than most other oxidizers e.g., oxygen or permanganate, therefore potentially establishing a higher electromotive force for fuel cell operation. However, the oxidation of peroxide to oxygen, reaction 2 expressed as in (5), is easy on both $\mathrm{Pt}$ and $\mathrm{Pd}$, and both reactions 1 and 2 occur together, as expressed in (6). The effect of this is that the open circuit potential is a mixed potential, occurring at about $0,85 \mathrm{~V}$ on $\mathrm{Pt}$ in acid solution.

Net reduction of hydrogen peroxide occurs only negative of this, so the actual over potential for direct hydrogen peroxide reduction is relatively high. The combination of the two reactions is the catalyzed decomposition of hydrogen peroxide to oxygen and water, $2 \mathrm{H}_{2} \mathrm{O}_{2} \rightarrow 2 \mathrm{H}_{2} \mathrm{O}+\mathrm{O}_{2}$.

Anodic systems based on formic acid have previously exhibited relatively high performance in terms of both current density and power density in micro fluidic fuel cells [7] as well as polymer electrolyte membrane fuel cells based on liquid fuels, such as the direct formic acid fuel cell [8].

The half-cell reaction and standard potential at $298 \mathrm{~K}$ of a formic acid-based anode is expressed in (7).

$\mathrm{CO}_{2}+2 \mathrm{H}^{+}+2 \mathrm{e}^{-} \leftrightarrows \mathrm{HCOOH}$

$\mathrm{E}^{\circ}=-0.199 \mathrm{~V}$ vs. SHE

A fuel cell based on hydrogen peroxide reduction and formic acid oxidation thus has a standard cell potential of $1,975 \mathrm{~V}$.

The fuel cell shown in Fig. 6 comprises two layers: a substrate upon which electrodes are formed, and a polymeric top layer housing the channel structure.

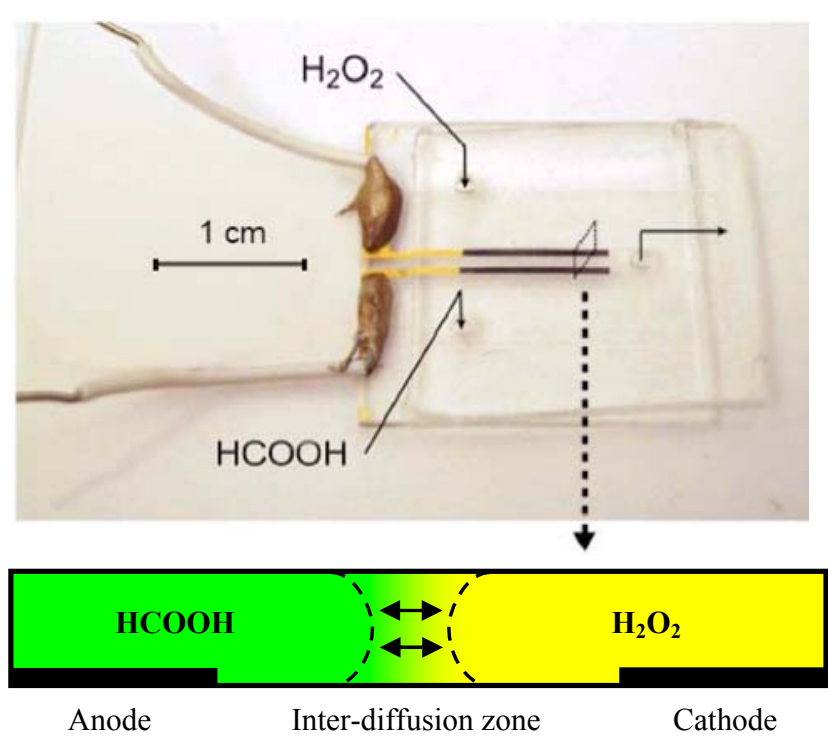

Figure 6. (Color online) Image of a micro fluidic fuel cell with Pd electrodes using formic acid (HCOOH) fuel and hydrogen peroxide $\left(\mathrm{H}_{2} \mathrm{O}_{2}\right)$ oxidant. The cross-section overview of the channel shows the inter-diffusion of anolyte and catholyte that is characteristic of co-laminar flow. The channels employed here were $2 \mathrm{~mm}$ wide and 70-170 $\mu \mathrm{m}$ high, and the electrodes were $0.5 \mathrm{~mm}$ wide and $10 \mathrm{~mm}$ in active length.

All the methods applied for the characterization of salts in this study, presented in the article "Characterization of potassium salts of 12-tungstophosphoric acid", confirm that in the synthesis of neutral or acidic salts, the reaction of WPA in concrete experiment with $\mathrm{K}_{2} \mathrm{CO}_{3}$, causes precipitation of $\mathrm{K}_{3}$ WPA. In the case of formation of acidic potassium salt, a mixture of $\mathrm{K}_{3}$ WPA and unreacted WPA is obtained. The nature of this mixture depends on the number of replaced protons-oxonium ions by cations. In the case of $\mathrm{KH}_{2} \mathrm{WPA}$ salt, a two-phase system of cubic crystals of WPA and mesoporous neutral $\mathrm{K}_{3} \mathrm{PWA}$ salt is formed. If the number of counter ions is $x \geq 2$, unreacted acid is dispersed over the grains of neutral salt. The effects of the interfaces in these heterogeneous systems, such as acid potassium salts of WPA, are of particular importance because of the (i) extremely high interfacial proportions and (ii) size effects that can affect the local transport properties [11]. If grain boundaries are composed of space-charge layers, the carriers can exhibit completely different transport properties along the core and space-charge layers [12]. Formation of extra defects in the space-charge region as a consequence of interface processes has a significant effect on ionic conductivity.

The results obtained in [8] confirm that insoluble potassium salts of WPA could be good candidates for application as proton exchange electrolytes 
in fuel cells due to their satisfactory proton conductivity between $7.2 \times 10^{-5}$ and $1.4 \times 10^{-4} \mathrm{~S} / \mathrm{cm}$. Also, their possible washing out from electrolyte or membrane is avoided in contrast to soluble WPA. Their conductivity at $80^{\circ} \mathrm{C}$ and $\mathrm{RH}=70 \%$ is $\sigma=102 \mathrm{~S} / \mathrm{cm}$ measured at a frequency of $100 \mathrm{kHz}$. The acidic $\mathrm{KH}_{2}$ WPA salt showed the best characteristics for this purpose which is in accordance with conductivity measurements and FT-IR data.

Although the investigated salts have shown good chemical stability and satisfactory conductivity, their application as potential material for fuel cells needs further technical improvements. We beli- eve that further significant mechanical and conductive improvements can be reached by incorporation of this class of compounds into inorganic substrates such as $\mathrm{SiO}_{2}, \mathrm{TiO}_{2}$ and $\mathrm{Al}_{2} \mathrm{O}_{3}$ or organic polymer such as polyaniline [13].

\section{FUEL CELL APPLICATIONS}

Application ranges of $\mathrm{FC}$ are given in Table 1 [9].

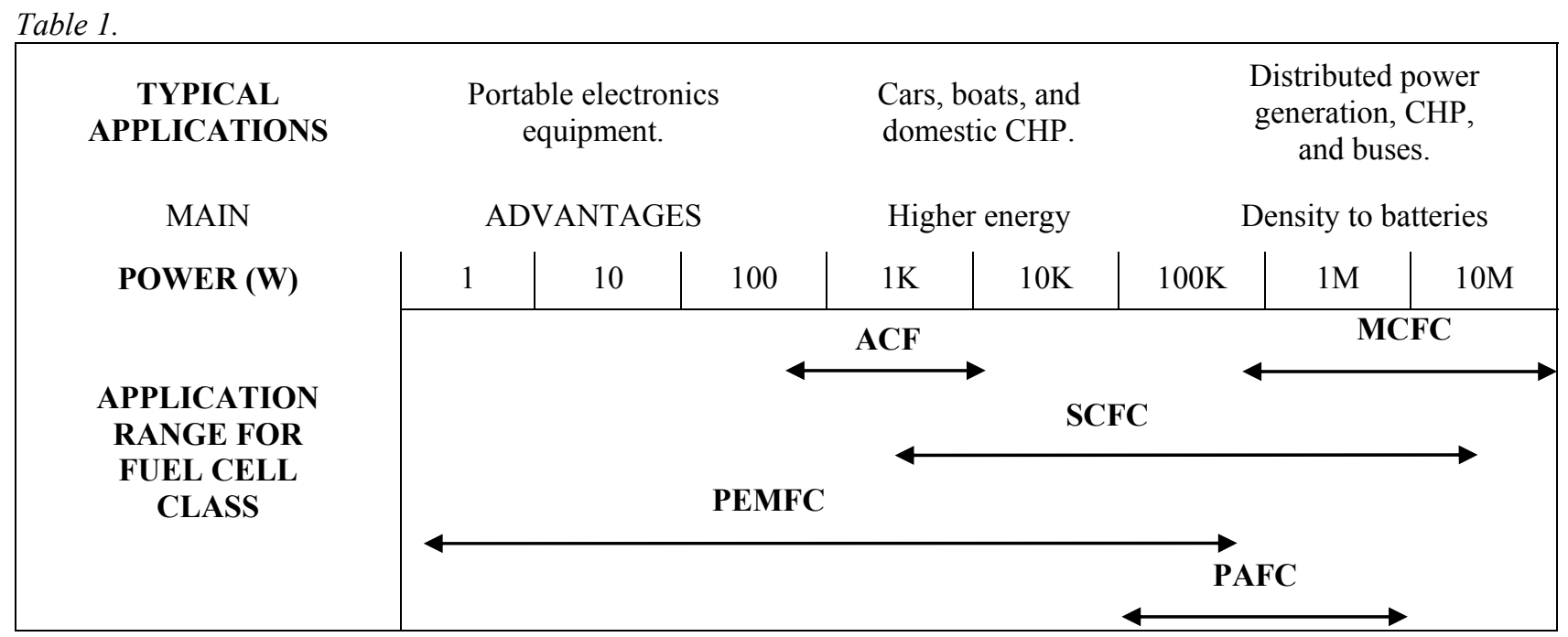

\section{CONCLUSION}

Heteropoly compounds have been widely studied in relation to their expressive conductive, catalytic, antiviral, photochromic and many other properties [10]. Among heteropoly compounds, 12tungstophosphoric acid hydrates, $\mathrm{H}_{3} \mathrm{PW}_{12} \mathrm{O}_{40} \cdot \mathrm{nH}_{2} \mathrm{O}$ (WPA $\cdot \mathrm{nH}_{2} \mathrm{O}, \mathrm{n}=29,21,14$ and 6) having Keggin structure, characterized by strong acidity are classified into "superacids". Systematic investigations of heteropoly acids (HPAs) and their alkali and alkaline-earth salts, the aim in this study was to examine whether insoluble potassium salts of WPA could be used as proton exchange electrolytes (PEE) in fuel cells. An important step towards better understanding and applying of PEEs is the characterization of their thermal, structural and conductive properties.

\section{ACKNOWLEDGMENTS}

This study has been supported by the Ministry of Science and Technological Development of the
Republic of Serbia, Grants No. 171021, 142047 , $141030 \mathrm{G}$ and TR-34028.

\section{REFERENCES} peroxide

[1] http://en.wikipedia.org/wiki/ Hydrogen

[2]http://www.peswiki.com/index.php/Directo ry:Hydrogen_Peroxide_as_Fuel

[3] Pradyot Patnaik. Handbook of Inorganic Chemicals. McGraw-Hill, 2002, ISBN 0070494398

[4] M. Davidovic, J. C. Badot, U. B.Mioč, Z. Nedić, Proceedings of Meeting, 9th International Meeting, "Fundamental problems of Solid State Ionics“, Russian Federation, Moscow region, Chernogolovka, June 24-27,2008, П-2.7., p. 275

[5] G. H. Miley, N. L. Mather, E. Byrd, G. Hawkins, G. Hawkins, L. Gu, A. Nayak, R. Burton and P. J. Shrestha, Optimization of the $\mathrm{H}_{2} \mathrm{O}_{2}-\mathrm{NaBH}_{4}$ Regenerative Fuel Cell For Space Power Applications Using FEMLAB Modeling, Excerpt from the Proceedings of the COMSOL Multiphysics User's Conference 2005 Boston, 
[6] E. Kjeang, A. G. Brolo, D. A. Harrington, N. Djilali and D. Sintona, Hydrogen Peroxide as an Oxidant for Microfluidic Fuel Cells, Journal of the Electrochemical Society $154 \quad$ (12) (2007) B1220-B1226.

[7] R. S. Jayashree, L. Gancs, E. R. Choban, A. Primak, D. Natarajan, L. J. Markoski, and P. J. A. Kenis, Air-Breathing Laminar Flow-Based Microfluidic Fuel Cell, J. Am. Chem. Soc., 127 (2005). 16758-16759.

[8] Y. M. Zhu, Z. Khan and R. I. Masel, J. Power Sources, 139, 15 (2005).

[9] J. Larminie, and A. Dicks, Fuel Cell Systems Explained, John Wiley and Sons, November 2000.

[10] I. Holclajtner-Antunović a, U.B. Mioč, M. Todorović, Z. Jovanović, M. Davidović, D. Ba-
juk-Bogdanović, Z. Laušević, Characterization of potassium salts of 12-tungstophosphoric acid, Elsevier, Materials Research Bulletin 45 (2010) 16791684.

[11] J. Jamnik, J. Maier, Charge transport and chemical diffusion involving boundaries, Solid State Ionics, 94 (1997) 189.

[12] J. Jamnik, Defect chemistry and chemical transport involving interfaces, Solid State Ionics, 119 (1999) 191-199.

[13] G.Ćirić-Marjanović , I. Holclajtner-Antunovic, S. Mentus, D. Bajuk-Bogdanović, D. Ješić, D. Manojlović, S. Trifunović, J. Stejskal, Selfassembled polyaniline 12-tungstophosphate micro/nanostructures, Synth. Met., 160 (2010) 1463-1473.

$\sec \theta$

\section{ГОРИВЕ ЋЕЛИЈЕ НА ОСНОВУ НЕКИХ СВОЈСТАВА ПРОТОНСКЕ ДИНАМИКЕ $\mathrm{H}_{2} \mathrm{O}_{2}$ ЈЕДИҢЕЊА}

Сажетак: У раду су представљена електрохемијска својства и својство проводљивости $\mathrm{H}_{2} \mathrm{O}_{2}$ једињења у зависности од амбијенталних услова. Бројне експерименталне технике и теоријски прорачуни примењивани су на овај проблем. Посебна пажња посвећена је једињењу хидроген-пероксид, молекуларне формуле $\left(\mathrm{H}_{2} \mathrm{O}_{2}\right)$, који је добијен из полиооксометал киселине, мале специфичне површине $\left(5 \mathrm{~m}^{2} / \mathrm{g}\right)$. Поменута својства се могу унапредити облагањем појединих проводника на транспарентном супстрату.

Кључне речи: горивне ћелије, водоник пероксид, простор наелектрисања. 